\title{
Whose Common Law for Labor Relations?
}

\author{
Paul R. Verkuil $†$
}

Richard Epstein attacks the New Deal for enacting the Wagner Act and thereby subverting the common law which, with "interstitial modification,"1 was well suited to deal with the problems of labor relations. Professor Epstein offers a radical critique of the New Deal and dismisses its intellectual contributions to the development of labor policy. Karl Klare had earlier done the same thing from an entirely different perspective. ${ }^{2} \mathrm{My}$ purpose is to say a few words on behalf of the deceased.

Let me add an ounce of history to Epstein's pound of logic. The opening words of The Common Law perfectly fit the occasion:

The felt necessities of the time, the prevalent moral and political theories, intuitions of public policy, avowed or unconscious, even the prejudices which judges share with their fellow-men, have had a good deal more to do than the syllogism in determining the rules by which men should be governed. ${ }^{3}$

Despite Professor Epstein's attempt to "put aside" conditions of labor unrest in the 1930s, ${ }^{4}$ we cannot be blind to the fact that in 1934 and 1935 labor-management relations and the economy were at a low ebb. There were strikes and violence which, according to historical reports, amounted to civil war in many communities. ${ }^{5}$ Moreover, with staggering unemployment and diminishing wages, it was difficult to accept the theory of com-

$\dagger$ Dean and Professor, Tulane University School of Law.

1. These words were part of the paper delivered by Professor Epstein at Yale in February, 1983. Since then the author has moderated his attack, and $I$ am at a loss to locate some of his more memorable phrases. Originally, the author was much more direct in his attack upon New Deal legislation at the time of its enactment. Since this Symposium was about the New Deal, I will still focus my comments on that period.

2. Professor Klare attacks the New Deal for undermining what he sees as the radical intention of the Wagner Act. See Klare, Judicial Deradicalization of the Wagner Act and the Origins of Modern Legal Consciousness, 1937-1941, 62 MINN. L. REV. 265 (1978). In some ways, being caught between the critiques of Epstein and Klare confirms the success of the balancing act the New Deal labor legislation sought to perform.

3. O.W. HOLMES, THE COMMON LAW 1 (1881). Since Epstein relies upon the common law as the basis for his critique of labor legislation, Holmes' view of how the common law emerges seems particularly relevant.

4. See Epstein, A Common Law for Labor Relations: A Critique of the New Deal Labor Legislation, 92 YALE L.J. 1357 (1983).

5. 2 A. SChlesinger, The Age of Roosevelt: The Coming of the New Deal 385 (1958). 
petition as a solution. Given that environment, it is hard to take seriously Epstein's premise that choosing to become an employer or employee "is strictly a private act."

Yet the New Deal did not accept the full implications of an economic determinism that the image of generations of coal miners in places like Harlan County might invite. Such a view of the world, if held by the Roosevelt administration, would have undermined any semblance of contractual theory in the employment context. But FDR was in fact no great champion of labor. ${ }^{7}$ On this score as on many others he was a pragmatist. $\mathrm{He}$ did recognize the rights of labor to organize as a part of the ill-fated National Recovery Act and later when he established the National Labor Board by presidential proclamation. ${ }^{8}$ In these efforts FDR conceded the obvious: Some federal supervision was necessary to maintain public order and to obtain greater equality of bargaining power. Given the times, this finger-on-the-scale approach must have been the minimal politically acceptable response and, accordingly, a necessary intrusion into what was an unbalanced and volatile market for labor. ${ }^{9}$

Thus New Deal labor-relations policy was informed not so much by conservative or radical theorizing as by incrementalization, a process whereby government control reacted to political necessity. The NorrisLaGuardia Act served more to implement this honest-broker approach of the New Deal than to upset existing labor-management understandings. The Wagner Act went beyond FDR's initial concessions and to that extent had a radicalizing potential. However, its implementation, as Professor Klare acknowledges, ${ }^{10}$ was a masterpiece of judicial and administrative temporizing. It is hard to second guess such a successful attempt to mediate among competing social values in a time of unprecedented upheaval.

Epstein's case for common law superiority in the face of these historical realities is seriously weakened. For common law theory to work, Epstein stipulates the "faithful enforcement" of agreements by the state." As Holmes reminds us, however, the prejudices of judges have much to do with the creation of the common law. In this case, prejudice could easily

6. Epstein, supra note 4, at 1366 .

7. See A. SCHLESINGER, supra note 5, at 402-03.

8. Id. at 150-51. FDR did what he could to ward off Senator Wagner's attempts to enact more far-reaching labor legislation in (what was later to become) the Wagner Act. Id. at 403.

9. Similar pressures led the Roosevelt administration to enact protective agricultural legislation to allow dairymen and farmers to organize so as to offset the market power of large dairies and supermarkets. See Block v. Consumer Nutrition Inst., 104 S. Ct. 2450, 2452-53 (1984) (describing the legislative background to the enactment of the Agricultural Marketing Agreement Act of 1937).

10. See Klare, supra note 2 , at 309-10.

11. See Epstein, supra note 4, at 1366. 
be found among judges who were unwilling to treat evenhandedly union attempts to organize labor.

One gets a feel for the judicial outlook in Chief Justice Taft's correspondence. In a letter to his cousin, Horace Taft, written in 1921, he said:

The only class which is distinctly arrayed against the court is a class that does not like the courts at any rate, and that is organized labor. That faction we have to hit every little while, because they are continually violating the law and depending on threats and violence to accomplish their purpose. ${ }^{12}$

If this attitude was prevalent in the judiciary, it must be true that in many communities the opportunities for unions to utilize common law tort remedies to enjoin illegal employer resistance to organization were nonexistent. Or, to place the matter in a more recent setting, the possibilities for neutral treatment by common law judges in labor cases in the 1930's were no greater than the chances of civil rights workers thirty years later to use the common law courts to protect themselves from violence in places like Holly Springs, Mississippi or Plaquemines Parish, Louisiana. In some communities the conditions for common law resolution of contract or tort problems did not exist. In Lockean terms, these are the communities where civil society had given away to a state of nature, at least for certain individuals or groups.

The controversy surrounding the yellow dog contract illustrates this problem of neutral application of common law doctrines. Epstein contends that a contract whereby a worker agrees not to become a member of a union ought to be respected in the same way as any other. No one can doubt that to be a proposition with broad appeal. However, the real world problem with yellow dog contracts was not that employers enforced them against employees, which would have been unnecessary since these employees had only contracts at will in any event. The problem was that the existence of such contracts allowed employers to obtain broad injunctions against unions for inducing or coercing breaches of those contracts. Judges with a predisposition against unions were willing to distort the common law by importing into the labor setting the tort principle of third-party inducement to breach from cases like Lumley v. Gye. ${ }^{13}$ Thus, in the early

12. H. PRingle, The Life and Times of William Howard TafT 967 (1939).

13. Lumley v. Gye, 2 E. \& B. 216,118 Eng. Rep. 749 (1853), involved a tort of malicious inducement of breach by Gye, who tried to get Johanna Wagner to sing for him while she was under exclusive contract to Lumley, a rival impresario. It was preceded by Lumley v. Wagner, $1 \mathrm{DeG}$., M. \& G. 604, 42 Eng. Reg. 687 (Ch. 1852), where Mme. Wagner was enjoined from breaching her exclusive contract. No such prior litigation against the employee was undertaken in the labor context because the employment contracts were not exclusive or for a term. The context therefore was entirely different, with the union being the only target of the employer's wrath. See C. GREGORY \& H. KATZ, 
1900's employers could have injunctions against labor-organizing activities, many of which were not unlawful in themselves, for the asking. ${ }^{14}$

Professor Epstein distorts the historical record in his discussion of Lumley v. Gye when he states that: "Both the English and American courts extended Lumley to ordinary labor contracts, finding the use of the injunction uncontroversial."1s In fact, the application of Lumley to the labor setting in England was a cause celebre at the turn of the century ${ }^{16}$ and led to a statutory reversal by Parliament of the common law that forbade damages actions as well as injunctions against unions. ${ }^{17}$ Thus, the reaction against Lumley in its own setting was even more emphatic, swift, and comprehensive than it was in the United States. It can only be accurate to say that Lumley was uncontroversial among the common law judges who extended it without much thought to the labor context. Once that occurred, however, the legislative reaction on both sides of the Atlantic made it clear how deep the controversy ran. By failing to appreciate the limits of precedent, common law judges in effect lost jurisdiction over the field of labor relations. ${ }^{18}$

Epstein relies heavily upon the connection between Lumley and Hitchman Coal \& Coke Co. v. Mitchell ${ }^{19}$ in constructing his argument in favor of yellow dog contracts. But Brandeis' dissent in Hitchman, which argued for a narrow legal definition of coercion, contained the more potent empirical point:

If it is coercion to threaten to strike unless plaintiff consents to a closed union shop, it is coercion also to threaten not to give one employment unless the applicant will consent to a closed non-union shop. The employer may sign the union agreement for fear that labor may not be otherwise obtainable; the workman may sign the individual agreement for fear that employment may not be otherwise obtainable. But such fear does not imply coercion in a legal sense. ${ }^{20}$

The problem for Brandeis was that the Court, in affirming the district judge, had permitted the common law principle of coercion to work in one direction only: against the union organizers but not against the employer who obtained the closed (non-union) shop agreement. Brandeis' approach,

LABOR AND THE LAW 93-95 (3d ed. 1979).

14. See generally F. FrankfurTER \& N. GReENe, THE LABOR INJUNCTION (1930).

15. Epstein, supra note 4, at 1374 (footnote omitted).

16. See generally O. KAHN-FREUND, LABOUR AND THE LAW 8-9, 251-64 (1977).

17. Trade Disputes Act, $1906,6 \mathrm{Edw}$. 7, c. 41 (creating a catalogue of economic torts that would not give rise to liability if committed in contemplation or furtherance of a trade dispute).

18. See O. KAHN-FREUND, supra note 16, at 18: "In the formulation of rules which regulate the relations between employers and workers the common law has played a minor role."

19. 245 U.S. 229 (1917)

20. Id. at 271 (Brandeis, J., dissenting) (emphasis in original). 
as a matter of common law interpretation, might have been one way for the courts to retain jurisdiction over the labor-management setting. By denying the ready application of inducement-to-breach actions against the union, as opposed to actions against the employees, employees could gather the countervailing strength to organize. Timing in this context was critical for both sides. If the union could not approach employees in sufficient numbers to organize resistance to the non-union shop, there could be no real possibility of success. Employers, with the instant availability of injunctions, could effectively stop union organizing in its tracks.

The yellow dog contract story tells us a lot about the viability of the common law in an age of statutes. In Adair v. United States ${ }^{21}$ and Coppage v. Kansas, ${ }^{22}$ two cases Epstein relies upon, the Court found that the Congress and state legislatures had specifically overruled the common law by statute in outlawing yellow dog contracts as early as $1898 .^{23}$ Thus the common law had been clearly displaced by popular will. It took the heroic measure of constitutionalizing prior common law principles in Adair and Coppage to vindicate the Epstein position. His complaints about the Norris-LaGuardia Act's doing violence to common law principles must be understood against this background of twenty years of prior legislative activity that sought to achieve the same result.

The Court refused to permit the statutory modification of the common law to take place. ${ }^{24}$ Epstein has accepted the Court's view of the common law by freezing its principles in time. The fallacy in this approach is that it can be implemented only by constitutional fiat, which is a far more rigid mode of decisionmaking than the process of statutory modification.

To maintain this premise about the superiority of common law solutions, Epstein must conclude that the common law would not have changed significantly over the last fifty years. ${ }^{25}$ Even in the absence of the New Deal administrative state, that proposition is dubious. The forces that led to the establishment of the Wagner Act, and the creation of the list of unfair labor practices Epstein decries, would have worked themselves out in a more fitful fashion directly upon the common law itself. As the "prejudices" of judges changed, so undoubtedly would the common law. It is unfair to hold the New Deal solutions up to the mirror of the common law doctrines which preceded the New Deal. What should be

\footnotetext{
21. 208 U.S. 161 (1908).

22. 236 U.S. 1 (1915).

23. Comparable legislative activity occurred in England in 1906. See supra note 17.

24. See G. CALABRESI, A COMMON LAW FOR THE AGE OF STATUTES 2-3 (1982) (arguing that statutes should be viewed as part of the common law).

25. To some extent Professor Epstein tries to avoid this argument by stipulating what he calls "the best set of private-law rules." Epstein, supra note 4, at 1359. But that level of abstraction just won't wash. It effectively contradicts the very process by which the common law rules emerge.
} 
done is to compare New Deal solutions with what the common law would have become had there not been a New Deal. That, of course, is impossible to do, but my hunch is that one of the reasons the early common law of contracts is still recognizable today is that we have relieved the system of some of the pressures which overarching social problems like labormanagement relations would have imposed upon it.

Moreover, as a practical matter it would be very difficult to put a lid on the assertion of rights under the labor laws even if it were possible to dismantle the formal apparatus of the NLRB. At the present time, the NLRB receives some 60,000 cases annually. ${ }^{26}$ Without the NLRB, a number of these grievances would at least initially have to be absorbed by the state or federal court system. At that point litigants would be subject to the vagaries of decisionmaking by judges whose understanding of labor relations would be rudimentary at best. This cannot help creating a confused jurisprudence that would itself, for some undefined period, serve to upset labor relations. The virtue of administrative decisionmaking is its predictability; in many industries that is a more significant factor than substantive outcome.

Perhaps these observations do Professor Epstein the disservice of taking his proposals too seriously. The critique of labor legislation from the common law perspective remains a powerful motif and raises the valid inquiry of whether New Deal solutions have run their course when the conditions which created them are no longer present. ${ }^{27}$ In the labor field, few have been bold enough to raise the deregulation banner, and one has to be indebted to Epstein for that effort. Similar exercises should be undertaken in analyzing the current viability of New Deal agricultural regulation. ${ }^{28}$ But that takes us far off course. For present purposes it is enough to establish that the New Deal did the job it was called upon to perform in the labor field at a time when common law solutions, however idealized in hindsight, were unavailable or counterproductive.

26. See 45 NLRB ANN. REP. (1980), reprinted in LABOR LAW REPORTS No. 1152, Feb. 2, 1982, at $1-2$.

27. It may be that Professor Calabresi's suggestion has validity in this context. He has proposed that when statutes become obsolete, the courts should have the ability to treat them as part of the common law and to revise them accordingly. G. CALABRESI, supra note 24, at 3-5. This is the corollary to Calabresi's principle that statutes ought to be regarded as part of the common law.

28. Attempts at agricultural deregulation by the Reagan Administration have so far floundered before entrenched interests. See Reagan Yields to the Kiwi Lobby?, N.Y. Times, July 3, 1984, at A15, col. 3. The historical justification for agricultural marketing orders, see supra note 9, is desperately in need of reexamination. 